\title{
SISTEM INFORMASI HIDROPONIK BERBASIS WEBSITE (HYDROPONIC AWAKENING REVOLUTION [HAR])
}

\author{
Nurul Kamilah ${ }^{1)}$, Dewi Primasari' ${ }^{2)}$, Erwin Hermawan ${ }^{3)}$ \\ ${ }^{1,2,3}$ Program Studi Teknik Informatika, Fakultas Teknik dan Sains, \\ Universitas Ibn Khaldun \\ E-mail : ${ }^{1}$ nurul.kamilah@uika-bogor.ac.id, ${ }^{2}$ dewiprimasari9@gmail.com, ${ }^{3}$ rwien.gfm@gmail.com
}

\begin{abstract}
ABSTRAK
Teknologi bercocok tanam dengan hidroponik pada umumnya dipelajari dengan datang dan bertanya langsung ke ahli. Hal tersebut tidak efisien dan membuang banyak waktu, apalagi dengan adanya pandemi Covid-19, proses belajar, penanaman, manajemen, pemasaran dan lain-lain menjadi terhambat karena diterapkannya kebijakan social distancing. Padahal, metode hidroponik dapat digunakan sebagai sarana meningkatkan pendapatan selama pandemi. Berdasarkan latar belakang permasalahan tersebut, dilakukan penelitian dengan tujuan untuk membangun sistem informasi hidroponik berbasis web yang memberikan pengetahuan dasar hidroponik, menyediakan wadah interaksi petani dan pakar hidroponik, dan jual beli hasil panen hidroponik. Petani muda yang baru belajar dapat memperoleh informasi hidroponik lewat membaca langsung di menu aplikasi, berkonsultasi langsung dengan pakar, dan bertanya lewat chatbot.
\end{abstract}

Kata Kunci: hidroponik, informasi, perdagangan.

\section{PENDAHULUAN 1.1. Latar Belakang}

Hidroponik adalah budidaya menanam tanpa menggunakan tanah, tapi menggunakan air. Air yang digunakan tidak sebanyak tanaman yang ada di tanah. Teknologi hidroponik ini merupakan salah satu teknologi pertanian yang memanfaatkan media air nutrisi dalam pertumbuhannya. Hidroponik saat ini menjadi trend di kalangan masyarakat. Selain mudah untuk proses penanamannya, perawatannya juga tidak sulit (Sarno, 2018).

Teknologi bercocok tanam dengan hidroponik pada umumnya dipelajari dengan datang dan bertanya langsung kepada ahli atau orang yang mengetahui tentang suatu topik tersebut. Metode ini juga dipelajari lewat media massa, media sosial dan informasi internet. Akan tetapi hal tersebut tidak efisien dan membuang banyak waktu. Apalagi dengan adanya pandemi Covid-19, proses belajar, penanaman, manajemen, pemasaran, dan lain-lain menjadi terhambat karena diterapkannya kebijakan social distancing. Padahal banyak masyarakat sebagai petani muda ingin mempelajari hidroponik sebagai salah satu cara menambah pendapatan selama pandemi.

Berdasarkan latar belakang permasalahan tersebut, penelitian ini dilakukan dengan tujuan untuk membangun sistem hidroponik berbasis web yang diharapkan dapat memberi pengetahuan dan media pemasaran pada masyarakat agar dapat mengembangkan hidroponik. Sistem informasi hidroponik ini memuat teori dasar hidroponik, media tanam dan alat-alat yang digunakan dalam hidroponik, langkah-langkah bercocok tanam hidroponik, sistem atau teknik yang ada pada hidroponik, produksi, manajamen, dan pemasaran hidroponik khususnya untuk para petani muda. Sistem ini juga memberikan sarana belajar kepada petani muda lewat membaca langsung di sistem dan bertanya jawab langsung dengan pakar atau lewat chatbot.

\subsection{Tinjuan Pustaka}

Hidroponik merupakan teknik budidaya tanaman tanpa menggunakan media tanah, melainkan menggunakan air sebagai media tanamnya. Keuntungan hidroponik adalah: (a) tidak memerlukan lahan yang luas (b) mudah dalam perawatan (c) memiliki nilai jual yang tinggi (Istiqomah, 2007).

Pengembangan teknologi dalam budidaya dengan sistem hidroponik menjadi salah satu alternatif yang dapat diterapkan untuk meningkatkan produktivitas cocok tanam dan sebagai upaya konservasi lahan di Indonesia (Suharto, 2016).

Media tanam tidak hanya sebatas menggunakan tanah dan air sebagai nutrisi pertumbuhan tanaman. Media tanam dapat menggunakan teknik hidroponik dengan menggunakan nutrisi A ataupun nutrisi B. Era modern seperti saat ini, media tanam hidroponik sangat membantu bagi skala rumah tangga yang tidak memiliki lahan kosong untuk bercocok tanam sehingga lahan yang sempit sekalipun dapat dimanfaatkan untuk menanam sayuran seperti bayam, tomat, sawi dan cabai (Istiqomah, 2007).

\subsection{Metodologi Penelitian}

Metode penelitian terdiri dari 6 tahapan yang dapat dilihat pada Gambar 1. 


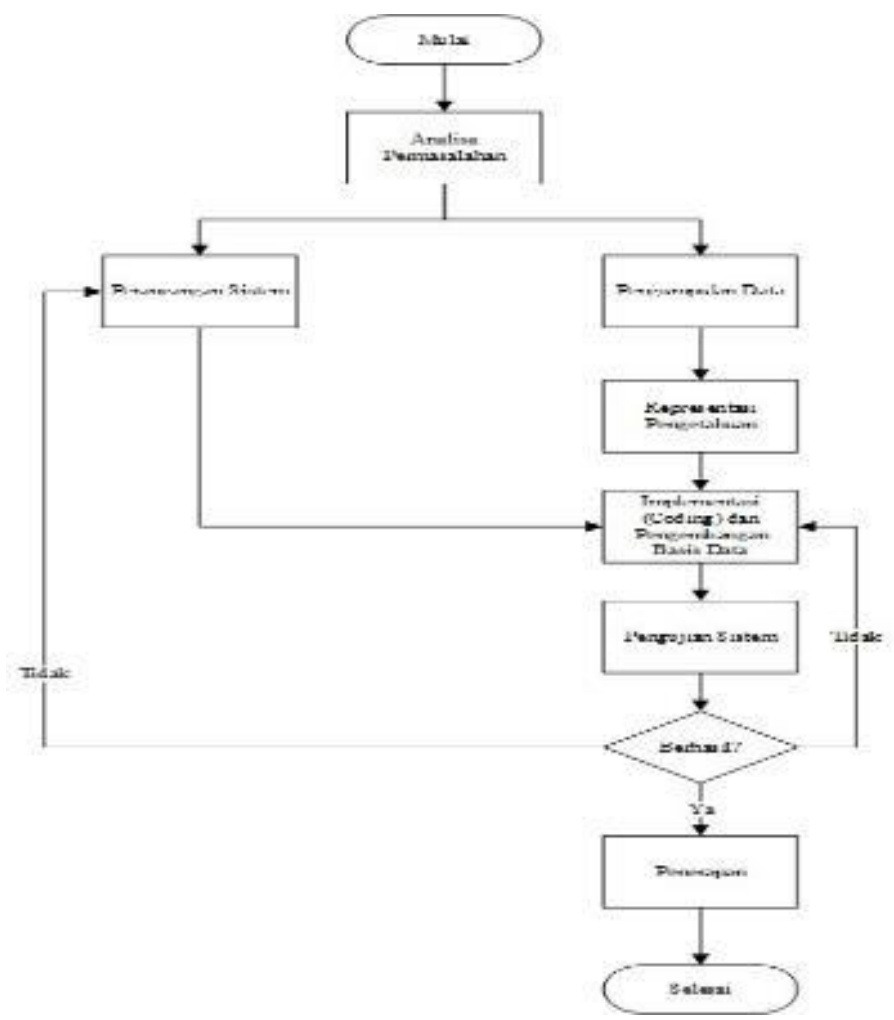

Gambar 1. Metode Penelitian

a. Analisis Masalah

Fase analisis masalah adalah dengan mencoba mengetahui kebutuhan user, mendaftar data yang dibutuhkan, dan mencari sumber daya manusia yang dibutuhkan untuk melakukan konsultasi (pakar).

b. Pengumpulan data

Proses pengumpulan data dilakukan dengan menggunakan teknik observasi lapangan yaitu mengamati, mencatat, merekam dan menyiarkan proses tumbuh hidroponik, serta menggunakan teknik wawancara untuk mengumpulkan pengetahuan dari para ahli.

c. Representasi Pengetahuan

Melaksanakan proses perancangan kodifikasi pengetahuan yang dirancang untuk representasi visual dari data/informasi. Desain data/informasi yang terkelompok dengan baik akan membantu mempercepat proses pencarian data atau informasi.

d. Implementasi (Coding)

e. Pengujian

Melakukan pengujian fungsi yaitu pengujian logika dan pengujian penerimaan pengguna dengan metode black box.

f. Penerapan

Implemetasi dan mematangkan keefektifan sistem manajemen data/informasi memerlukan sumber daya manusia dan finansial yang banyak. Walaupun memerlukan waktu lama, tahap ini sangat penting untuk meningkatkan keuntungan sistem secara signifikan. Pengelolaan data/informasi perlu dilakukan agar sistem selalu menyajikan data/informasi yang relevan dan bermanfaat bagi pengguna

\section{PEMBAHASAN}

2.1. Analisis Masalah

Hasil analisa infrastruktur sumber daya manusia melalui wawancara terhadap ketua komunitas hidroponik dipilih beberapa anggota komunitas yang ditunjuk sebagai sumber data/informasi tentang budidaya hidroponik seperti pada Tabel 1 .

Tabel 1. Infrastruktur Sumber Daya Manusia

\begin{tabular}{|c|c|}
\hline Sumber Daya Manusia & Kepakaran \\
\hline Ramdhoni & $\begin{array}{c}\text { Pakar Hidroponik (Mitra } \\
\text { Hidroponik) }\end{array}$ \\
\hline Syaugi Lettuce Farm & Usaha Hidroponik ( \\
& Marketing Hidroponik) \\
\hline
\end{tabular}

Secara umum, hasil analisa data dengan mitra terdapat 16 data/informasi untuk pemula yang ada berkaitan dengan budidaya sayuran hidroponik dan 3 data/informasi yang berkaitan dengan jual beli hasil panen sayuran hidroponik. Data berbentuk softcopy maupun hardcopy diperoleh dari Ramdhoni dan Syaugi Lettuce Farm, sisanya diambil dari wawancara pada pakar hidroponik. Hasil analisa data yang dibutuhkan terdapat pada Tabel 2. Sumber daya manusia terdiri dari pihak peneliti maupun komunitas yang terbagi menjadi pakar hidroponik, pengembang, anggota dan umum seperti pada Tabel 3 . 
Tabel 2. Data yang Dibutuhkan

\begin{tabular}{|c|c|}
\hline No. & Data \\
\hline 1. & Data hidroponik untuk pemula \\
\hline 2. & Data alternatif pengganti rockwoll \\
\hline 3. & Data bio pestisida \\
\hline 4. & Data cara menentukan ukuran pompa \\
\hline 5. & Data efisiensi energi dan sarana produksi \\
\hline 6. & Data hidroponik murah \\
\hline 7. & Data kalibrasi $\mathrm{pH}$ meter \\
\hline 8. & Data mengatasi kendala dalam hidroponik \\
\hline 9. & Data optimasi input nutrisi \\
\hline 10. & Data optimasi pertumbuhan tanaman melalui \\
\hline 11. & Data pengendalian hama dan penyakit tanaman \\
\hline 12. & Data TDS-EC meter \\
\hline 13. & Data Pengalaman media tanam \\
\hline 14. & Data instalasi sistem hidroponik \\
\hline 15. & Data penanganan hama \\
\hline 16. & Data penggunaan nutrisi \\
\hline 17. & Data jenis tanaman tanaman hidroponik \\
\hline 18. & Data harga hasil panen hidroponik \\
\hline 19. & Data stok hasil panen hidroponik \\
\hline
\end{tabular}

Tabel 3. Sumber Daya Manusia

\begin{tabular}{|c|c|c|}
\hline Jabatan & Sumber Daya & Keterangan \\
\hline $\begin{array}{c}\text { Pakar } \\
\text { Hiroponik }\end{array}$ & $\begin{array}{c}\text { Ramdhoni } \\
\text { Syaugi Lettuce } \\
\text { Farm }\end{array}$ & $\begin{array}{l}\text { Pakar yang menjadi } \\
\text { sumber pengetahuan } \\
\text { hidroponik, mereka } \\
\text { terdiri dari pengurus } \\
\text { maupun anggota } \\
\text { komunitas. }\end{array}$ \\
\hline $\begin{array}{c}\text { Pengembang } \\
\text { Aplikasi }\end{array}$ & $\begin{array}{c}\text { Nurul Kamilah } \\
\text { Dewi Primasari } \\
\text { Erwin } \\
\text { Hermawan }\end{array}$ & $\begin{array}{c}\text { Orang yang } \\
\text { mengembangkan sistem } \\
\text { informasi budidaya } \\
\text { hidroponik. }\end{array}$ \\
\hline Petani & $\begin{array}{c}\text { Anggota } \\
\text { komunitas atau } \\
\text { masyarakat } \\
\text { umum }\end{array}$ & $\begin{array}{c}\text { Orang yang mengambil } \\
\text { pengetahuan tentang } \\
\text { budidaya hidroponik } \\
\text { yang telah terdata } \\
\text { sebagai anggota } \\
\text { komunitas di luar pakar. }\end{array}$ \\
\hline Anggota & $\begin{array}{c}\text { Masyarakat } \\
\text { umum }\end{array}$ & $\begin{array}{l}\text { Orang yang melakukan } \\
\text { pembelian hasil panen } \\
\text { hidroponik yang telah } \\
\text { terdata sebagai anggota } \\
\text { komunitas di luar pakar } \\
\text { dan petani. }\end{array}$ \\
\hline
\end{tabular}

\subsection{Pengumpulan Data}

Pada tahap ini banyak data berasal dari dokumen modul pelatihan hidroponik seperti pada Tabel 2, sedangkan sisanya didapatkan melalui teknik on-site observation melalui foto dan rekaman video secara langsung di lapangan.

Data yang diambil untuk melengkapi kebutuhan informasi terdiri dari pengalaman budidaya sayuran hidroponik seperti persiapan media tanam, mengatur nutrisi, instalasi sistem serta penanganan hama. Proses pengambilan data dilakukan bersama pakar komunitas yang bertujuan mendapatkan data berupa pengalaman budidaya hidroponik berbentuk foto dan video interaktif yang contoh capture-nya dapat dilihat pada Gambar 2.

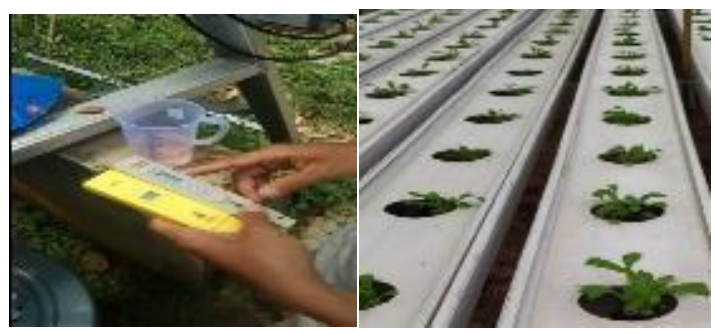

Gambar 2. Proses Pengumpulan Data

Proses budidaya sayuran hidroponik terdiri dari 4 tahapan yaitu instalasi hidroponik, membuat larutan nutrisi, persiapan tanaman, dan pemeliharaan tanaman. Pemetaan kebutuhan data/informasi untuk mendukung tahapan budidaya tersebut yang mengacu pada ketersediaan infrastruktur pengetahuan dapat dilihat di Tabel 4.

Tabel 4. Ketersediaan Data

\begin{tabular}{|c|c|c|}
\hline No. & $\begin{array}{c}\text { Tahap } \\
\text { Budidaya } \\
\text { Hidroponik }\end{array}$ & Ketersediaan data \\
\hline 1. & $\begin{array}{c}\text { Instalasi } \\
\text { hidroponik }\end{array}$ & $\begin{array}{c}\text { - } \quad \text { Menentukan ukuran pompa. } \\
\text { - } \quad \text { Pengalaman instalasi sistem } \\
\text { hidroponik. }\end{array}$ \\
\hline 2. & $\begin{array}{c}\text { Membuat } \\
\text { larutan nutrisi }\end{array}$ & $\begin{array}{l}\text { - } \\
\text { Pengalaman mencampur } \\
\text { nutrisi AB mix. } \\
\text { - } \quad \text { Pengaturan optimasi input } \\
\text { nutrisi dan pH. } \\
\text { TDS-EC meter danuan penggunaan meter. }\end{array}$ \\
\hline 3. & $\begin{array}{l}\text { Persiapan } \\
\text { tanaman }\end{array}$ & $\begin{array}{l}\text { - } \quad \text { Penyiapan media tanam. } \\
\text { - Alternatif pengganti rockwoll. }\end{array}$ \\
\hline 4. & $\begin{array}{c}\text { Pemeliharaan } \\
\text { tanaman }\end{array}$ & $\begin{array}{c}\text { - } \\
\text { Pengalaman penanganan } \\
\text { hama. } \\
\text { - Penggunaan bio pestisida. }\end{array}$ \\
\hline
\end{tabular}




\subsection{Representasi Pengetahuan}

Pengetahuan sistem hidroponik dikembangkan dengan jaringan semantik. Pengetahuan disusun dalam node (lingkaran) dan link (tanda panah) seperti terlihat pada Gambar 3.

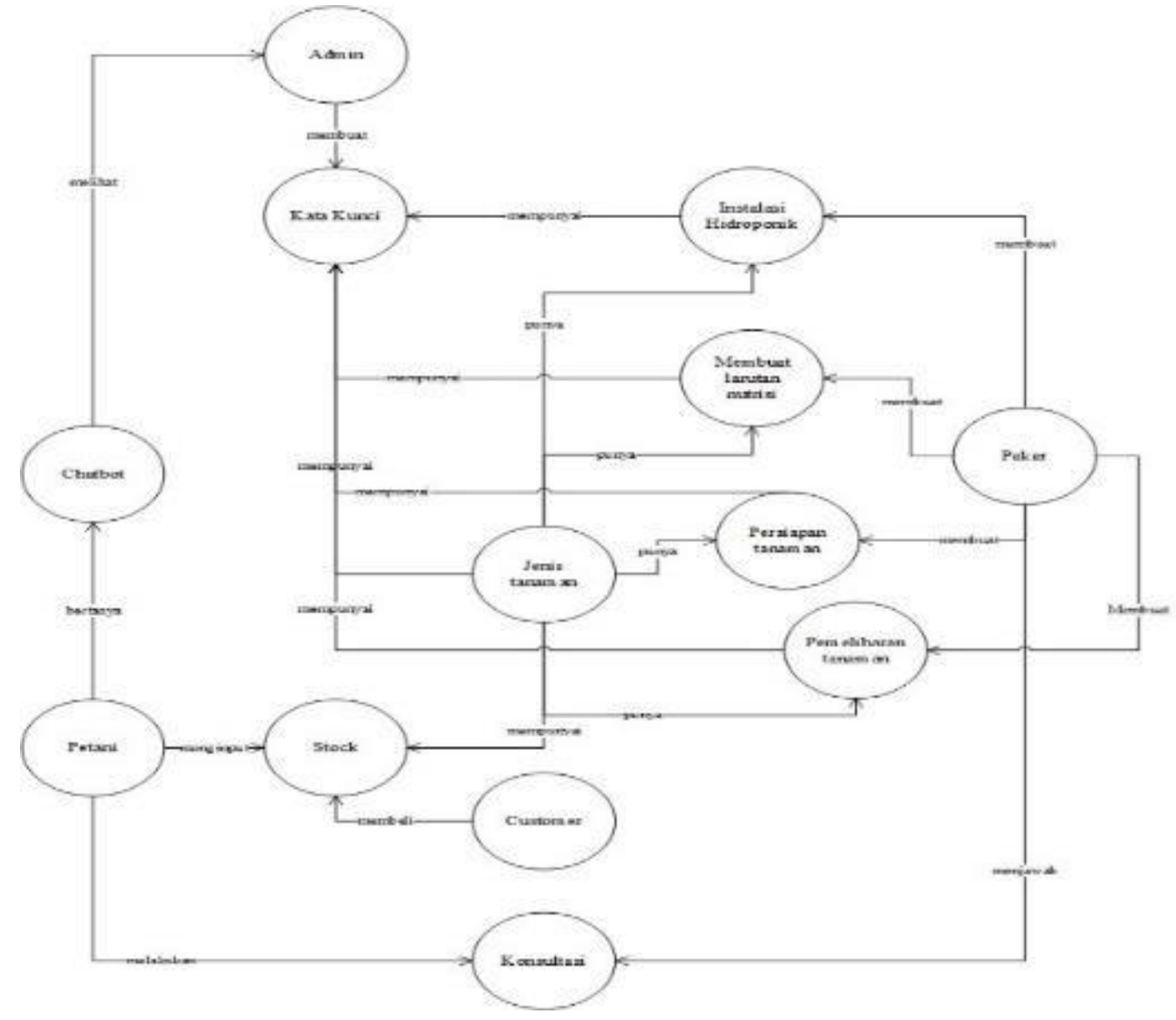

Gambar 3. Representasi Pengetahuan

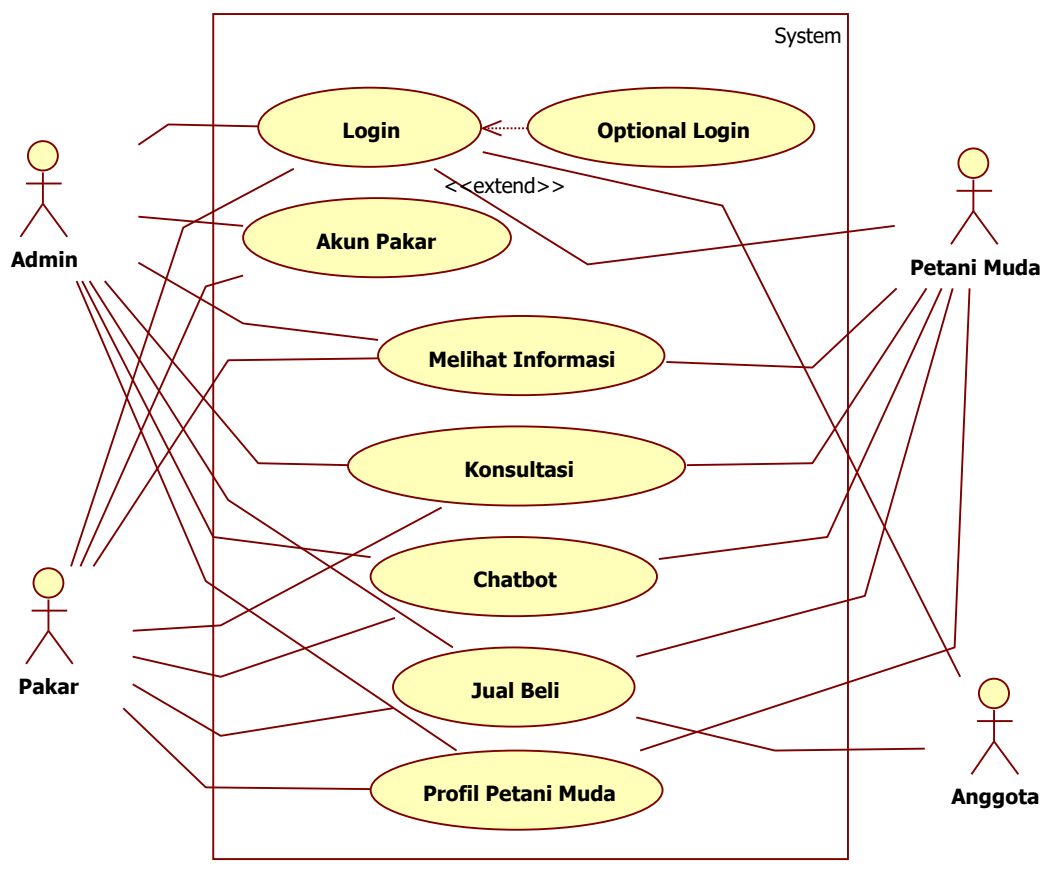

Gambar 4. Use Case Diagram 
Langkah berikutnya adalah melakukan perancangan kebutuhan fungsional aplikasi berdasarkan aktor yang terlibat dalam lingkungan sistem. Terdapat empat aktor yaitu admin, pakar, petani, dan pembeli dapat dilihat pada Gambar 4.

Login dapat dilakukan melalui sistem atau melalui opsional login Google/Facebook. Selanjutnya, setiap pakar dapat membuat akun masing-masing dan menginputkan data/informasi budidaya hidroponik beradasarkan teori atau pengalaman. Setelah data/informasi awal terbentuk, petani muda dapat melakukan profiling dan mencari data/informasi tentang hidroponik. Bila ada pertanyaan, petani muda dapat bertanya lewat chatbot atau langsung berkonsultasi dengan pakar yang diinginkan. Pasca panen, petani muda dapat melakukan jual beli di dalam sistem setelah meninputkan jenis barang, stok barang, dan harga barang. Transaksi terbatas hanya pada sesama anggota user sistem hidroponik ini.

Setelah desain UML selesai, selanjutnya dilakukan proses implementasi rancangan fungsional menggunakan aplikasi berbasis website dengan framework Codeigniter berbahasa pemrograman PHP. Hasil implementasi sistem untuk fitur mencari pengetahuan pengguna dapat memasukan kata kunci pencarian pengetahuan pada chatbot, lalu sistem akan memproses kata kunci dengan menilai kemiripan kata kunci terhadap deskripsi dokumen melalui proses pembobotan dokumen pengetahuan sesuai dengan kata kunci.

\subsection{Validasi dan Verifikasi Knowledge Management System}

Pengujian sistem dilakukan dengan cara mengecek hasil kodifikasi pengetahuan dengan pakar, sedangkan pengujian penerimaan pengguna digunakan metode pengujian black box untuk meminta pakar menguji fungsi aplikasi dengan melihat keluaran yang dihasilkan.

\subsection{Hasil Implementasi Sistem}

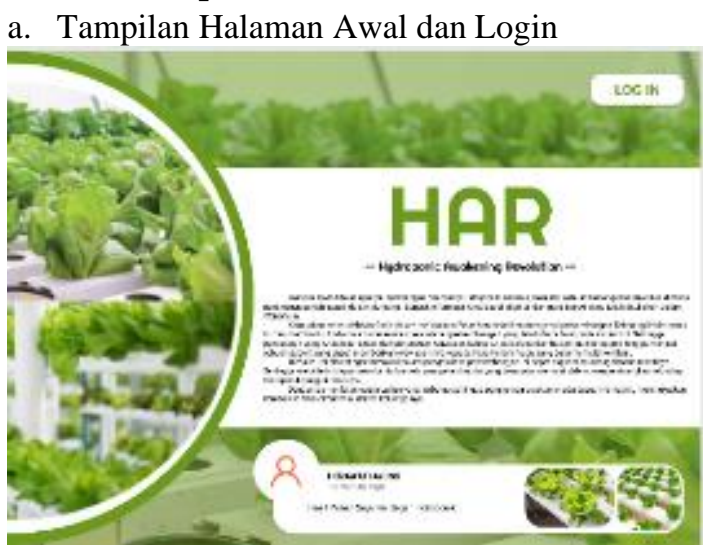

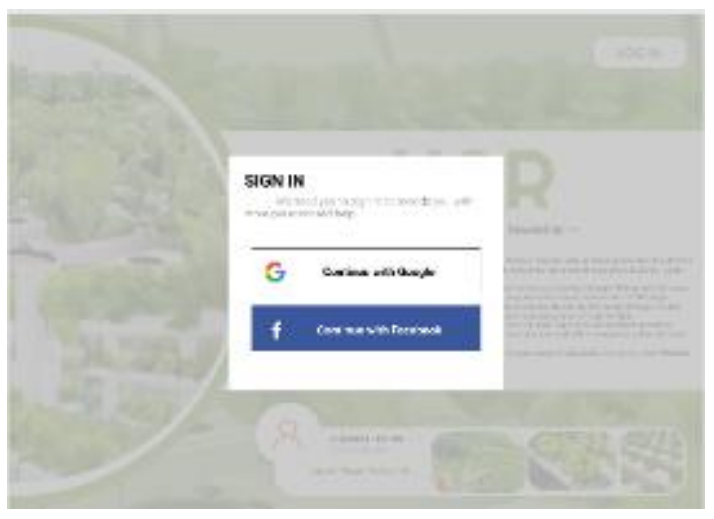

Gambar 5. Halaman Awal (atas) dan Halaman Login (bawah)

Halaman awal sistem informasi hidroponik yang diberi nama Hydroponic Awakening Revolution (HAR) ini menampilkan informasi umum tentang tujuan dan gambaran singkat sistem ini (Gambar 5a). Untuk login dapat dilakukan lewat sistem atau Google/Facebook (Gambar 5b).

\section{b. Optional Login}
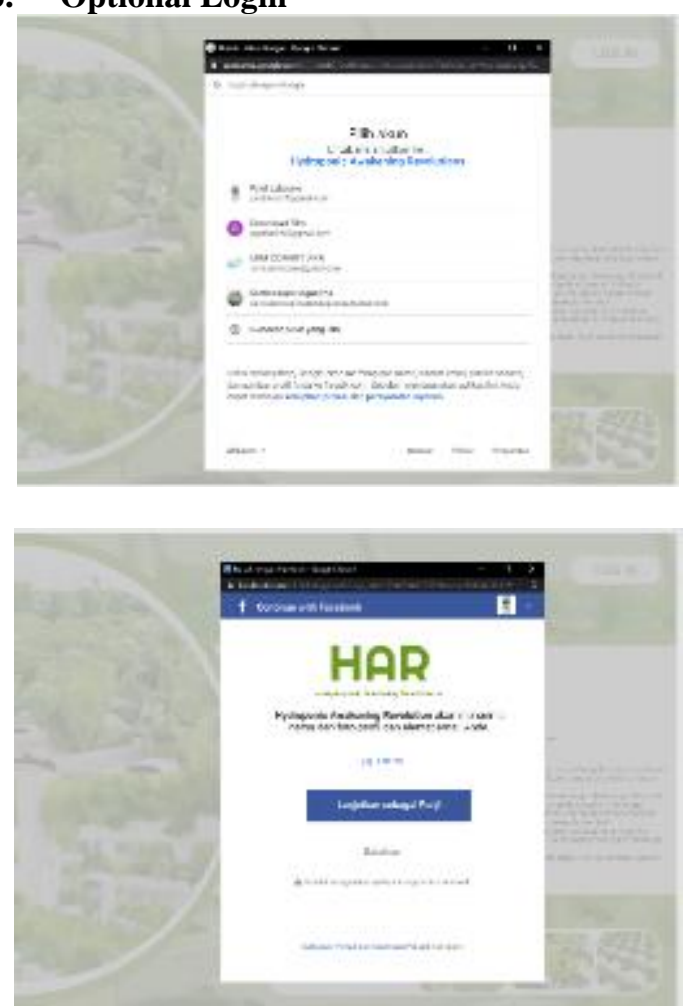

Gambar 6. Contoh Optional Login dengan Facebook (atas) dan Pemilihan Akun (bawah)

Gambar 6 (atas) menampilkan contoh login lewat pilihan selain sistem, yaitu lewat Facebook. Selanjutnya, tampil pertanyaan tentang akun yang facebook yang akan dipakai (gambar 6 bawah).

\section{c. Beranda}




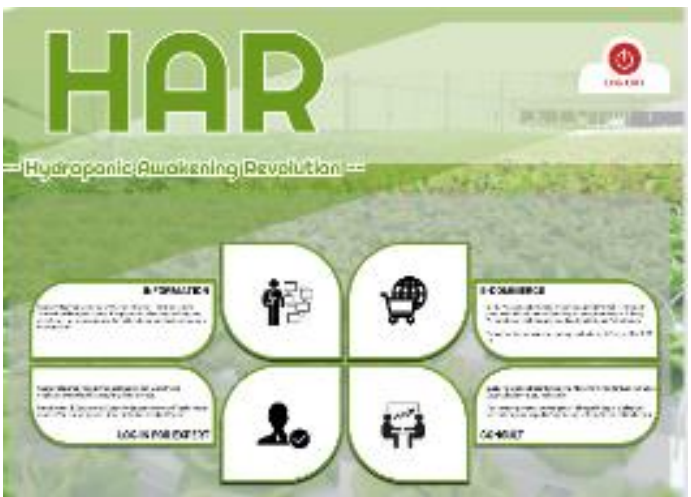

Gambar 7. Halaman Beranda

Setelah login berhasil, maka halaman yang tampil adalah halaman beranda. Tampilan beranda pada gambar 7 adalah beranda petani muda, di mana menu yang ditampilkan adalah informasi hidroponik, mengunduh file tentang materi hidroponik, jual beli, dan kontak para anggota.

\section{d. Akun Pakar}

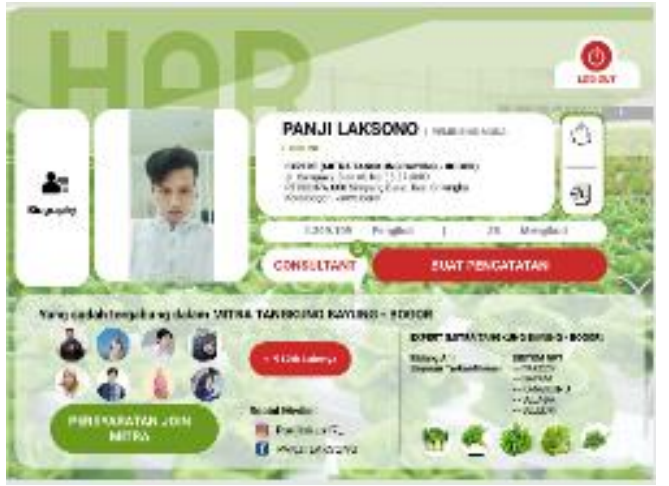

Gambar 8. Akun Pakar

Halaman akun pakar digunakan oleh pakar untuk melalukan pemberian materi dan menjawab pertanyaan yang diajukan petani muda selama konsultasi.

\section{e. Information}

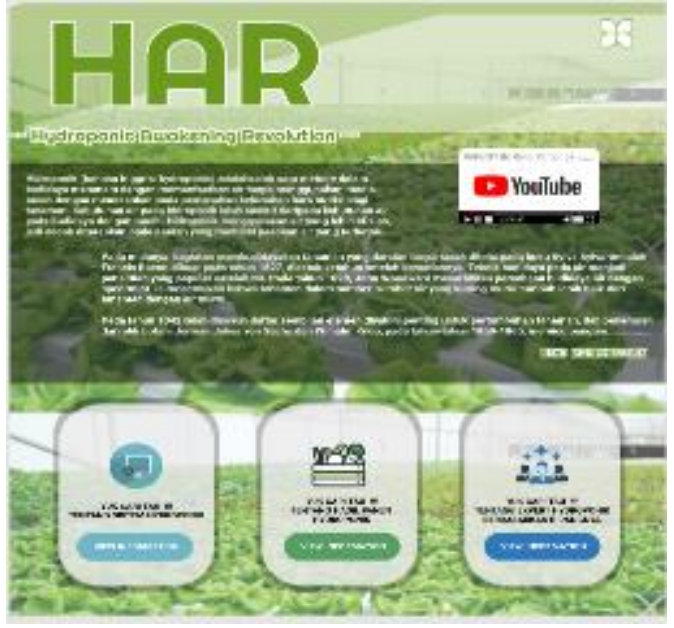

\section{Gambar 9. Halaman Informasi}

Halaman informasi memberikan informasi budidaya hidroponik lewat teks maupun video via yotube (Gambar 9).

\section{f. Konsultasi}

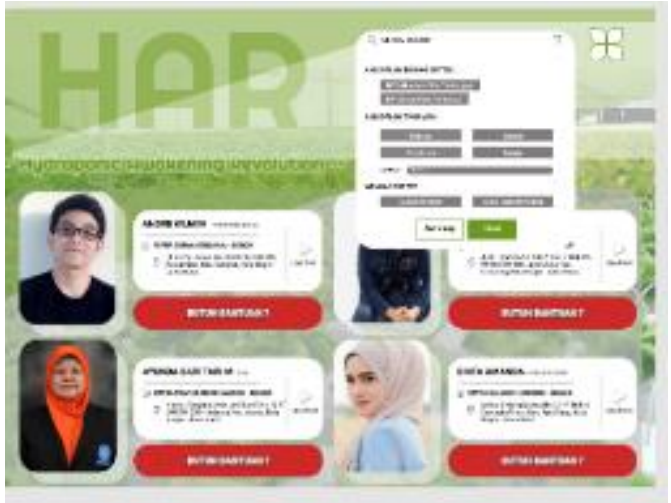

Gambar 10. Halaman Konsultasi

Halaman konsultasi merupakan tempat petani muda untuk bertanya pada pakar hidroponik yang diinginkan (Gambar 10).

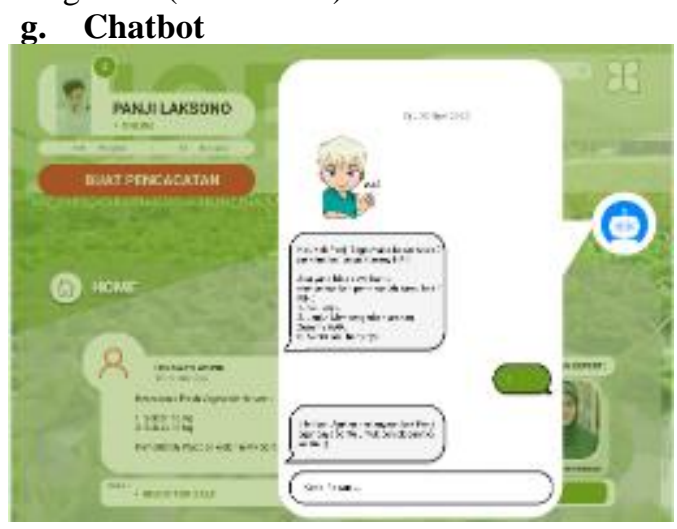

Gambar 11. Halaman Chatbot

Chatbot mendukung pemberian informasi dari pertanyaan petani muda. Informasi yang ditampilkan berdasarkan kata kunci yang diinputkan (Gambar 11).

\section{h. Jual Beli}

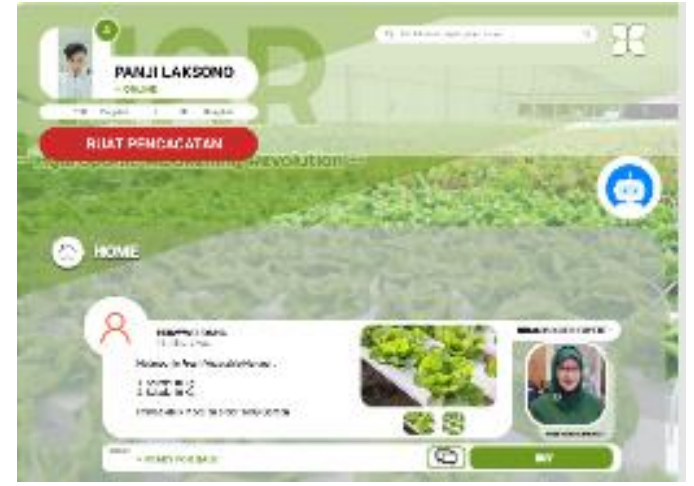




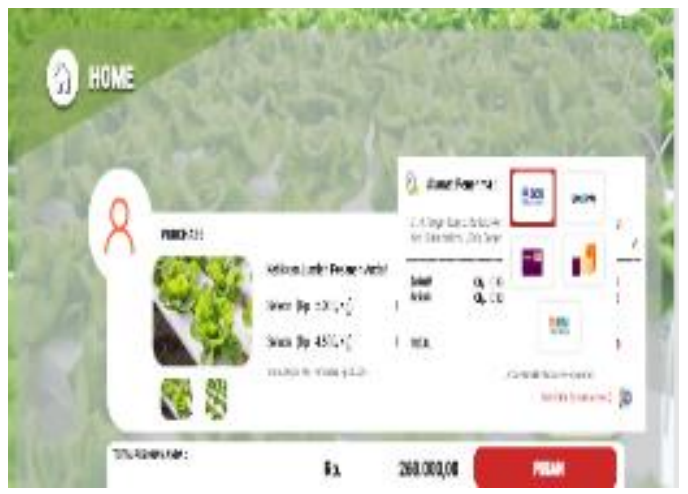

Gambar 12. Halaman Jual Beli (atas) dan Halaman Detail Transaksi Jual Beli (bawah)

Halaman jual beli dapat dilakukan antara petani muda dengan seluruh actor yang bertipe petani atau bertipe anggota. Gambar 12 (atas) menampilkan petani yang berlaku sebagai penjual hasil panennya, stok yang tersedia dan harga jual, sedangkan gambar 12 (bawah) menampilkan detail transaksi yang terjadi antara penjual dan anggota.

\section{E. Verifikasi dan Validasi Knowledge Management System}

Pengujian logikal meliputi pengujian hasil kodifikasi pengetahuan melalui pakar untuk proses validasi pengetahuan. Selanjutnya dilakukan pengujian penerimaan pengguna, pengujian berdasarkan fitur utama klasifikasi KMS yang terdiri dari beberapa fungsi yang dihasilkan dari fitur mencari pengetahuan, mengelola pengetahuan, dan mengelola komentar.

\section{KESIMPULAN}

a. Budidaya hidroponik dikembangkan sebagai sarana untuk berbagi pengetahuan yang dapat dimanfaatkan oleh masyarakat. Sistem ini sudah berhasil dirancang dan dikembangkan menggunakan pendekatan Knowledge Management Sytem Life Cycle sampai tahap 6 awal. Diharapkan sistem ini dapat disempurnakan sampai tahap 8.

b. Di masa mendatang diharapkan knowledge capture dan jumlah pakar konsultasi lebih banyak sehingga petani lebih luas wawasan pengetahuannya tentang hidroponik. Konsultasi juga dilengkapi dengan chat BOT.

\section{PUSTAKA}

Sarno, 2018. Pemberdayaan Masyarakat Desa Pagak Banjarnegara Melalui Transfer Teknologi Hidroponik Sayuran Organik. Jurnal Pengabdian Masyarakat | ADIMAS (Online), Jilid 2, No. 1 , (http://journal.umpo.ac.id/index.php/adimas/ article/view/900, diakses 18 Februari 2021)
Istiqomah, Siti. 2007. Menanam Hidroponik. Jakarta : Azka Press.

Suharto, 2016. Peengembangan Sistem Hidroponik untuk Budidaya Tanaman Kentang (Solanum tuberosum L.). Jurnal Keteknikan Pertanian 04(2):1-8. 